\title{
OPTIMIZED SUBSURFACE IRRIGATION SYSTEM (OPSIS). THE FUTURE OF SUGARCANE IRRIGATION
}

\author{
Muhammad Sarwar ${ }^{1}$, Arshad Mahmood ${ }^{2}$, Waqas Raza Arshad ${ }^{3}$ \& Khalid Mehmood ${ }^{4}$ \\ 1. Agronomist, Soil Salinity Research Institute, Pindi Bhattian. \\ 2. Assistant Research Officer, Sugarcane Research Institute, Faisalabad.
}

3. Research Officer, Sugarcane Research \& Development Board, Faisalabad

4. Assistant Statistician, Statistical Section, Faisalabad

Email: sarwarmuhammad28@gmail.com

\section{ABSTRACT}

An experiment was conducted in Sugarcane Research Institute (SRI) Faisalabad during 2017 2018 and 2018-2019 cropping seasons to find out the effect of different irrigation levels on growth and yield parameters of five sugarcane clones. Sugarcane is a tropical crop with C4 Photosynthetic metabolism. Due to irrigation water shortages, water stress is common in sugarcane. Major Responses of drought in sugarcane is leaf rolling. Stomatal Closure inhibition of stalk and leaf growth, leaf senescence and reduced leaf area (due to its phenomenal dry matter production capacity) are other symptoms of water stress.

\section{Keywords: Sugarcane, irrigation, intervals}

\section{INTRODUCTION}

\section{Sugarcane}

(Saccharum officiriarum L.) is one of the most important crops in the world. Its plays a vital economic role in sugar and bio energy production. Although Sugarcane can tolerate some moisture stress, it still has a high-water requirement to the range of $1500-2500 \mathrm{~mm}$ per season in order to achieve yields close to the potential maximum.

Water is of vital importance for Sugarcane Production. For better juice quality and higher cane yields assured moisture is necessary. During the entire growth period Sugarcane required a constant supply of moisture in the soil, Inadequate water supply acta as a retarding factor in nutrient update and reduces the yield. Proportionately, in addition the maturity pattern, sugar Accumulation, levels as well as the chemical composition of juice are altered to a considerable extent moisture stress during the formative phase causes considerable reduction in cane yield and sucrose accumulation. Water shortage generally results in reduction of growth and yield. There will be pressure to resort to producing Sugarcane with less irrigation water in the future. The use of drought tolerant varieties is the more economic way to get around the water stress problems. According to Landell and Salva (2008) studies concerning agronomic traits in different water regimes, however were undertaken with specific genotypes. Number of millable stalks has been reduced under restricted water availability. Stalk diameter has been found to be influenced by water regimes, however it is also dependent of the genotype, Costa E Silva et al. (2004) and/or harvest cycle (Soares et al, 2004). Cane elongation and stalk height are severely and strongly effectuated under drought conditions (Inman-Bamber and Smith 2005, Costa E Silva 2008 and Silva et al, 2007). As a result 
of the reduction in agronomic traits associated with yield cane and sugar yields are decreased under water stress conditions. Stalk number and water node number were reduced by water stress especially in the plant cane crop.

\section{MATERIALS AND METHODS}

Two fields experiments were conducted in the research experimental farm of Sugarcane Research Institute Faisalabad during the successive seasons of 20172018 and 2018-2019. Five Sugarcane clones were cultivated to study the effect of irrigation regimes on Sugarcane yield and its components 15 plots 9plot size 38-4m2) for each treatment were used to carry out the experiments. Daily rainfall of the experimental field was also measured to enable the precise calculation of the water use efficiency of irrigation treatments. The three budded and double setts planting method with $1.2 \mathrm{~m}$ spacing between rows was used in all treatments. Experiments were conducted to observe growth and yield with 3-irrigation levels i.e.

$11=1.0$ coefficient

$1_{2}=0.8$

$1_{3}=0.6$

Rainfall was measured using a recording rainguage that was installed at the site. The portion of rainfall that can be effectively used by the plants was calculated using the procedure as explained by Brouwer and Heibloem.

Water use efficiency (WUE)

Irrigation Water use efficiency (IWUE) = $\underline{\text { Cane }}$ yield (t/ha)

The significance of treatments differences was tested by analysis of variance (ANOVA) for each variable in order to assess the main effects of water treatment and Sugarcane clones as well as Sugarcane clones * water regime interaction. Means were separated by using the least significant difference test (LSD). The data on germination\% tillers/plant no of mill able cane/ha, cane yield t/ha and CCS\% were recorded by using the standard procedure. The data was analysed by employing the fisher's analysis of variance technique (steel et al, 1999) compare the difference among treatments means with LSD text at 0.05 probability level.

\section{RESULTS AND DISCUSSION}

\section{Germination Percentage}

The effect of different irrigation regimes and growth behavior of five sugarcane clones were studied during two successive years 2017-18 and 2018-19. The protocol data on fire aspects like germination\%, tillers per plant 000 canesha $^{-1}$, cane yield tha $^{-1}$ and CCS\%\&were recorded that is elaborated in this mants scaipd. yitethe (tllata) in table-1 revealed that Sugarcane clones gave statistically significant germination i.e. 55.40 at irrigation level 1 which were followed by others two respectively i.e. 53.62 and 51.95.

As far as sugarcane clones were concerned, the sugarcane clone S2008-AUS130 gave the significantly higher germination\% i.e. 56.90 as compared to other four sugarcane clone that's have the lower germination. These findings are in accordance with the Mehboob et al, (2000) stated different sugarcane clone have their own growth character.

\section{Tillers per Plant}

The perusal of pool data of two successive years for tillers per plant shown in table-2 revealed that treatments of different irrigation levels have statistically non-significant effect the sugarcane clones showed statistically significant effect. The sugarcane clones i.e. S2008AUS-130, S2005-US-54, S2008-AUS-134 and S2003US-127 gave statistically significant no of tiller/plant e.g. $1.12,1.13,1.09,1.01$, respectively but the 
sugarcane clone CPF-249 gave less no of tillers/plant i.e. 0.91 . The results of reported by (Sarwar et al, 2017) are in accordance with the present findings.

\section{No. of 000 canes/ha}

It is obvious from the data given in table -3 that the irrigation regimes have a significant effect on no. of canes and on stalk diameter in both years. Applying irrigation water at intervals of $12-15$ days i.e. $l_{1}=1.0$ coefficient produced more no of millable canes which are statistically significant and followed by other two irrigation levels. The irrigation level $\mathrm{I}_{3}=0.6$ co-efficient, having irrigation interval of 30-35 days, gave statistically a smaller number of mill able canes. These results are in compliance with results reported by Gomes (2000) and Bekheet (2006). Secondly the four sugarcane clones produced the statistically same no. of millable canes/ha. The clones with nomenclature S2008AUS-130, S2003-US-127, S2005-US-54 and0.91. S2008-AUS-134 produced 105.09, 104.69, 103.38, and 102.83 respectively. The sugarcane clone CPF-249 statistically produced less no. of mill able cane/ha because it is the variety characteristics. These findings are in accordance with Sarwar et al, 2019

\section{Cane/Yield ha}

The result in table-4 obtained that the differences between the studies irrigation regimes had significant effect on cane yield in both years. The data also showed that in a linear fashion with increasing irrigation intervals the maximum reduction being at the longest interval in both years. The result in accordance with GOMAS (2000). The results in table showed that the irrigation level $I_{1}$ and $I_{2}$ significantly increased cane yield as compared to third regime through the two successive years 2017-18 and 2018-19. The results are contradicting with Azzazy and El.Geddawy,(2003). The irrigation regime $\mathrm{I}_{1}$ i.e. co efficient gave the statistically significant cane yield $108.46 \mathrm{t} / \mathrm{ha}$ which followed by $2^{\text {nd }}$ irrigation level $\mathrm{I}_{2}=0.8$ coefficient $103.22 \mathrm{t} / \mathrm{ha}$. The third irrigation level $I_{3}=0.60 \mathrm{co}$ efficient produced the statisticTable No. 5.ally less cane yield of 89.53 t/ha.0.91.0.91. As far as the sugarcane clones were concerned S2008-AUS-130 and S2003-US-127 produced statistically significant cane yield i.e. 105.43 and 104.96 tonnes/ha as compared to others. The sugarcane clone CPF-249 produced statistically less cane yield 94.17 tonnes per ha. In addition to this the Sugarcane clones S2008-AUS-130 and S2008-AUS-134 gave the better response i.e. 95.23 and 91.13 cane yield tonnes/ha as compared to other three sugarcane clones on water deficit/third irrigation level.

\section{Commercial cane Sugar Percentage}

As regards the commercial cane sugar percentage pooled data of two years exhibited that different irrigation regimes, had nonsignificant differences among the treatments. However, the sugarcane clone gave the statistically significant differences on average basis e.g. S2003-US-127 showed $14.40 \%$ which was followed by S2008-AUS-130 gave $14.03 \%$. The sugarcane clones S2005-US-54 and S2008-AUS-134 produced statistically less CCS\% i.e. 12.81 and 12.70. The interaction between irrigation regime and Sugarcane clone on equality parameter were not significant among the two successive years. 


\section{CONCLUSIONS}

Average data presented in summery table revealed that sugarcane clone S2008AUS-130 gave the highest germination percentage, tillers per plant, number of thousand canes/ha and cane yield. Similarly, irrigation level 1 facilitated germination percentage, tillers per plant, number of thousand canes/ha and cane yield. S2003-US-127 gave maximum $\mathrm{CCS} \%$ at irrigation level 2 and was calculated as $13.70 \%$.

Table-1

\begin{tabular}{|l|l|l|l|l|}
\hline Sugarcane clones & \multicolumn{3}{|c|}{ Irrigation Levels } & Average \\
\cline { 2 - 5 } & $\mathbf{1}$ & $\mathbf{2}$ & $\mathbf{3}$ & \\
\hline S2008-AUS-130 & 57.95 & 56.77 & 55.97 & 56.90 \\
\hline S2003-US-127 & 53.96 & 51.11 & 51.53 & 52.20 \\
\hline S2005-US-54 & 56.66 & 53.16 & 50.63 & 53.48 \\
\hline S2008-AUS-134 & 55.90 & 52.85 & 52.02 & 53.59 \\
\hline CPF-249 & 52.50 & 54.20 & 49.62 & 52.11 \\
\hline Average & 55.40 & 53.62 & 51.95 & \\
\hline
\end{tabular}

Table-2

\begin{tabular}{|c|c|c|c|c|}
\hline \multirow[t]{2}{*}{ Sugarcane clones } & \multicolumn{3}{|c|}{ Irrigation Levels } & \multirow[t]{2}{*}{ Average } \\
\hline & 1 & 2 & 3 & \\
\hline S2008-AUS-130 & 1.07 & 1.19 & 1.11 & $1.12 \mathrm{~A}$ \\
\hline S2003-US-127 & 1.03 & 0.95 & 1.04 & $1.01 \mathrm{AB}$ \\
\hline S2005-US-54 & 1.01 & 1.12 & 1.26 & $1.13 \mathrm{~A}$ \\
\hline S2008-AUS-134 & 1.14 & 1.07 & 1.05 & $1.09 \mathrm{~A}$ \\
\hline \begin{tabular}{|l|} 
CPF-249 \\
\end{tabular} & 0.90 & 0.85 & 0.97 & $0.91 \mathrm{~B}$ \\
\hline \begin{tabular}{|l|} 
Average \\
\end{tabular} & 1.03 & 1.04 & 1.09 & \\
\hline
\end{tabular}

Table-3

\section{Sugarcane clones}

S2008-AUS-130

S2003-US-127

S2005-US-54

S2008-AUS-134

CPF-249

Average
Number of 000 canes/ha Irrigation Levels 2

\begin{tabular}{|l|l|l|}
\multicolumn{3}{|c}{ Irrigation Levels } \\
\hline $\mathbf{1}$ & $\mathbf{2}$ & $\mathbf{3}$ \\
\hline 1.07 & 1.19 & 1.11 \\
\hline 1.03 & 0.95 & 1.04 \\
\hline 1.01 & 1.12 & 1.26 \\
\hline 1.14 & 1.07 & 1.05 \\
\hline 0.90 & 0.85 & 0.97 \\
\hline 1.03 & 1.04 & 1.09 \\
\hline
\end{tabular}

\begin{tabular}{|l|l|}
\hline Average \\
\hline & $1.12 \mathrm{~A}$ \\
\hline $1.01 \mathrm{AB}$ \\
\hline $1.13 \mathrm{~A}$ \\
\hline $1.09 \mathrm{~A}$ \\
\hline $0.91 \mathrm{~B}$ \\
\hline
\end{tabular}

Table-4

\begin{tabular}{|l|ll|l|l|}
\hline Sugarcane clones & \multicolumn{3}{|c|}{ Irrigation Levels } & Average \\
\cline { 2 - 5 } & $\mathbf{1}$ & $\mathbf{2}$ & $\mathbf{3}$ & \\
\hline S2008-AUS-130 & 112.50 & 108.55 & 95.23 & $105.43 \mathrm{~A}$ \\
\hline S2003-US-127 & 116.28 & 110.37 & 88.24 & $104.96 \mathrm{~A}$ \\
\hline S2005-US-54 & 107.85 & 101.07 & 88.07 & $99.00 \mathrm{~B}$ \\
\hline S2008-AUS-134 & 103.69 & 100.59 & 91.13 & $98.47 \mathrm{~B}$ \\
\hline CPF-249 & 101.99 & 95.50 & 58.01 & $94.17 \mathrm{C}$ \\
\hline AveraTable No. 5.ge & $108.46 \mathrm{~A}$ & $103.22 \mathrm{~B}$ & $89.53 \mathrm{C}$ & \\
\hline
\end{tabular}


DOI: $10.35380 /$ sugar.034.04.0150

Table-5

\begin{tabular}{|l|ll|l|l|}
\hline Sugarcane clones & \multicolumn{3}{|c|}{ Irrigation Levels } & Average \\
\cline { 2 - 5 } & $\mathbf{1}$ & $\mathbf{2}$ & $\mathbf{3}$ & \\
\hline S2008-AUS-130 & 112.50 & 108.55 & 95.23 & $105.43 \mathrm{~A}$ \\
\hline S2003-US-127 & 116.28 & 110.37 & 88.24 & $104.96 \mathrm{~A}$ \\
\hline S2005-US-54 & 107.85 & 101.07 & 88.07 & $99.00 \mathrm{~B}$ \\
\hline S2008-AUS-134 & 103.69 & 100.59 & 91.13 & $98.47 \mathrm{~B}$ \\
\hline CPF-249 & 101.99 & 95.50 & 58.01 & $94.17 \mathrm{C}$ \\
\hline Average & $108.46 \mathrm{~A}$ & $103.22 \mathrm{~B}$ & $89.53 \mathrm{C}$ & \\
\hline
\end{tabular}

\section{REFERENCES}

Azzazy, N.B. \& El-Geddawy, I.H. (2003). Effect of nitrogen fertilization on yieod and quality of some sugar cane varieries under developed surface irrigation system. Egypt journal of agricultural Research. 81(3): 1137-1147.

Costa E Silva, A. Shvaleva, J. P. Maroco, M. H. Almeida, M. M. Chaves and J. S. Pereira, 2004. Responses to water stress in two Eucalyptus globulus clones differing in drought tolerance. Tree Physiology 24, 1165-1172.

Inman-Bamber, N. G.; Smith, D. M. 2005. Water relations in sugarcane and response to water deficits. Field Crops Research. 2005; 92:185-202.

M.A. Silva, R.A.B. Soares, M.G.A. Landell and M.P. Campana, 2007. Agronomic performance of sugarcane families in response to water stress. Proc. Int. Soc. Sugar Cane Technol., Vol. 26, 2007.

Marcelo de Almeida Silva, Jorge Alberto Gonçalves da Silva, Juan Enciso, Vivek Sharma and John Jifon, 2008. Yield components as indicators of drought tolerance of sugarcane. Sci. Agric. (Piracicaba, Braz.), v.65, n.6, p.620-627.

Mahboob, A., F. Ahmad., G. Ali., S. Ali and S. Afghan, 2000. Effect of moisture regimes and fertilizers level on yield and yield parameters of spring sugarcane. PSJ 15(5): 2-6.

Sarwar, M., A. Mahmood, N. Ahmad and M. Yasin.2017. Biometric efficiency of sugarcane promising and commercial clones at different locations in central Punjab. Pak. Sugar J. 32(04): 10-13.

Sarwar, M. 2019. Proficiency of Sugarcane Clones/Varieties at Different Locations in Thal and Southern Punjab. Pak. Sugar J. 34(02): 08-12.

Steel, R.G.D, J.H. Torrie and D.A. Dickny, 1999. Principles and procedures of statistics. A biometric approach $3^{\text {rd }}$ Edition, McGraw Hills Book Co. Inc., New York, USA. 352-358. 